\title{
The Desire for Sons and Excess Fertility: A Household- Level Analysis of Parity Progression in India
}

By Sanjukta

Chaudhuri

Sanjukta Chaudhuri is assistant professor

Department of

Economics, University

of Wisconsin,

Eau Claire, WI, USA. CONTEXT: The desire for sons often influences fertility behavior in India. Women with a small number or low pro-
portion of sons may be more likely than other women to continue childbearing.

METHODS: Data from India's 2005-2006 National Family Health Survey were used to examine several hypotheses regarding the association between sex composition of children and parity progression among parous women aged 35-49. Descriptive analyses and multivariate logistic regression analysis that controlled for possible confounders were performed separately by parity.

RESULTS: Women with more sons than daughters were generally less likely than those with more daughters than sons to continue childbearing; parity progression driven by the desire for sons accounted for $7 \%$ of births. At any given parity, the last-born child of women who had stopped childbearing was more likely to be a son than a daughter (sex ratios, 133-157). In multivariate analyses, women without any sons were more likely than women without any daughters to continue childbearing at parities 1-4 (odds ratios, 1.4-4.5). At most or all parities, continued childbearing was positively associated with having had a child who died, and negatively associated with levels of women's education and media exposure and with household wealth.

CONCLUSIONS: The desire for sons appears to be a significant motivation for parity progression. Although population policies that reduce family size are essential, also imperative are policies that reduce desire for sons by challenging the perception that sons are more valuable than daughters. International Perspectives on Sexual and Reproductive Health, 2012, 38(4):178-186, doi: 10.1363/3817812
Sons are considered more valuable than daughters in India. Son preference is deeply rooted in various patriarchal practices, including a patrilineal inheritance system, a patrilocal marriage system, the social custom of dowry and the dependence of aging parents on sons. ${ }^{1-9}$ A major demographic outcome of son preference is that the proportion of living sons in a family influences the probability that the parents will procreate further. Known variously as differential stopping behavior, ${ }^{10,11}$ son-targeting fertility behavior ${ }^{1}$ and asymmetric procreation behavior, ${ }^{12}$ childbearing driven by a desire for sons occurs when parents continue to progress to higher parities, within a maximum limit, until they have the desired number of sons.

Parity progression driven by a desire for sons has several demographic and health ramifications. First, if prenatal sex detection and abortion are unavailable, parental desire for a certain number of sons will increase the average family size. Biologically, only $26 \%$ of couples who want two sons will have fulfilled this desire after two births. ${ }^{12,13}$ Even after having six children, about $10 \%$ of couples will have been unable to achieve their goal of having two sons. Thus, to the extent that it is the prevalent means of fulfilling the desire for sons, parity progression delays India's demographic transition by keeping fertility rates higher than they would be otherwise, because parents who have not achieved their "son target" continue to procreate. . $^{12,15}$
Indeed, the desire for sons is positively associated with the desire for more children ${ }^{16,17}$ and the total fertility rate, ${ }^{18}$ and negatively associated with contraceptive use. ${ }^{16,17}$ In Nepal, for example, the fertility rate is about $6 \%$ higher than it would be in the absence of son preference. ${ }^{15}$

Second, parity progression driven by a desire for sons may result in imbalances in the sex ratio by family size. Although the desire for sons has considerable bearing on fertility, it does not distort the overall population sex ratio; ${ }^{19}$ if parity progression is the only method of fulfilling the desire for sons, then the population will be large but balanced. However, the desire for sons can skew the sex ratio by family size: Smaller families will have a disproportionate number of sons, because parents whose first children are male may decide to stop childbearing, while larger families will have a disproportionate number of daughters, because parents whose first children are daughters will likely continue having children. ${ }^{1,10}$ Consequently, boys will tend to grow up in smaller families with fewer siblings and girls in larger families with more siblings, and girls will be more likely than boys to be born at earlier parities. ${ }^{1}$

The third probable consequence of son preference is the occurrence of gender disparities in health, education and other outcomes. In larger families, fewer household resources are available for each child. In an environment of son preference, daughters are less likely than sons to 
receive resources, ${ }^{20-23}$ which can result in undernutrition, wasting, stunting and even excess infant mortality. In addition, because daughters are more likely than sons to have younger siblings, they may be required to perform household chores and provide child care to younger family members, even if such chores come at the cost of their educational attainment. ${ }^{24}$

The gender disparities in infant health outcomes may be due, in part, to duration of breast-feeding. Because breastfeeding inhibits conception, parents who desire sons may wean daughters more quickly than they do sons, thus expediting the conception of the next (preferably male) child. Consistent with this scenario, studies conducted in South Asia ${ }^{15,25}$ and Africa ${ }^{26}$ have found that birth intervals are shorter after the birth of a daughter than after the birth of a son. In India, the median duration of breast-feeding is shorter for daughters than for sons, and this difference not only may lead to gender disparities in child health but may explain $9 \%$ of the excess female infant mortality in India. ${ }^{21}$

Although India has one of the world's oldest population programs and is a signatory to various international instruments and agreements aimed at eliminating gender bias, the country's population policy has not directly addressed son preference as a source of excess fertility and gender disparities. ${ }^{17,27,28}$ Given that India is expected to become the world's most populous country by $2025,{ }^{29}$ examining the relationship between the desire for sons and excess fertility in India is important for understanding patterns and determinants of fertility and in exploring appropriate population policies.

\section{Current Study}

Most studies on son desire and fertility in India have focused on the relationship between the sex ratio of the living children in a family and measures of intended (rather than actual) fertility. ${ }^{16-18}$ These include studies on the association between the number of sons and such variables as contraceptive use, desire for more children and whether the last birth was wanted. Not much attention has been paid to systematic statistical analysis of the relationship between the sex composition of a family's living children and realized fertility, as measured by probability of parity progression. Although Arnold and colleagues have studied this relationship in India, ${ }^{20}$ using data on eight states from the first (1992-1993) National Family Health Survey, their analysis was narrow and did not focus on how the desire for sons affects the relationship between family size and sex ratio of children. Although they controlled for other correlates of parity progression, such as mother's education, they did not discuss the implications of these correlates for parity progression driven by desire for sons.

The current study presents a robust analysis of the impact of the desire for sons on parity progression in India by assessing the relationship between sex composition of children and continued childbearing. The analysis examines several hypotheses regarding the desire for sons as a motivation for parity progression. The first hypothesis is that at earlier parities, the proportion of daughters will be positively associated with the probability of parity progression. Second, at any given parity, the last-born child of a woman who has stopped childbearing is likely to be a son. Consequently, the third hypothesis is that the sex ratio (number of males for every 100 females) will be unevenly distributed across family size: Smaller families will have a disproportionately high number of sons, while larger families will have a disproportionately high number of daughters. Finally, the proportion of daughters in a family will remain positively associated with parity progression after adjustment for socioeconomic factors.

This study also compares, at each parity, the sex ratio at birth of the last-born child of women who stopped childbearing with the corresponding ratio for women who continued to the next parity.

\section{DATA AND METHODS \\ Sample and Variables}

India's 2005-2006 National Family Health Survey (NFHS3 ), the third in a series of nationwide household surveys using random samples, provided the data for this study. The NFHS-3 obtained demographic and socioeconomic information on 124,385 ever-married women aged 15-49 years who had had a total of 280,870 live births. Women provided information on the number of sons and daughters who were living in the household, had left the household or had died; the birth order of each child; and age at death for any deceased children.

The current analysis is restricted to women who had given birth to at least one child and had completed childbearing. It follows Park and $\mathrm{Cho}^{19}$ in assuming that women aged 35-49 had completed childbearing. * A total of 37,441 respondents satisfied the age and fertility conditions. Of these, 875 respondents were excluded because they had had one or more multiple births (twins, triplets, etc.) at any parity. After exclusion of respondents for whom complete information on socioeconomic characteristics was unavailable, the final sample consisted of 33,245 women who had had 112,805 births.

The sample was divided by parity and sex composition, resulting in 14 predictor variables: parity 1 ( 0 or 1 son), parity 2 ( 0,1 or 2 sons), parity 3 ( $0,1,2$ or 3 sons), and parity 4 ( $0,1,2,3$ or 4 sons). "Sex composition" in this study refers to all possible combinations of sons and daughters at a given parity, without regard for birth order. The dependent variables were four binary variables on women's parity progression: whether they progressed from parity 1 to 2 , from parity 2 to 3 , from parity 3 to 4 , and from parity 4 to 5 . Although only birth orders up to five were analyzed, at each parity the sample included women who may have continued to parity 6 or beyond. Four multivariate binary

\footnotetext{
*The rationale for this assumption is that in the NFHS-3, $42 \%$ of women in this age-group reported that they had no desire for more children, and another $49 \%$ indicated that they had been sterilized; $6 \%$ said they had been declared infecund; $2 \%$ said they wanted to have more children; and fewer than $1 \%$ said they were undecided. Thus, $91 \%$ of women aged $35-$ 49 had completed childbearing or did not wish to continue childbearing.
} 


\begin{tabular}{|c|c|}
\hline Characteristic & $\begin{array}{l}\text { Mean or \% } \\
(\mathrm{N}=33,245)\end{array}$ \\
\hline MEANS & 41 \\
\hline Age gap with husband (yrs.) & 5.7 \\
\hline Media exposure index score & 3.6 \\
\hline \multicolumn{2}{|l|}{ PERCENTAGE DISTRIBUTIONS } \\
\hline None & 45 \\
\hline Primary & 16 \\
\hline Secondary & 30 \\
\hline >secondary & 8 \\
\hline \multicolumn{2}{|l|}{ Woman has occupation } \\
\hline Yes & 45 \\
\hline No & 55 \\
\hline \multicolumn{2}{|l|}{ Husband's education } \\
\hline None & 24 \\
\hline Primary & 17 \\
\hline Secondary & 43 \\
\hline >secondary & 16 \\
\hline \multicolumn{2}{|l|}{ Husband has occupation } \\
\hline Yes & 97 \\
\hline No & 3 \\
\hline \multicolumn{2}{|l|}{ Standard of living } \\
\hline Low & 24 \\
\hline Medium & 18 \\
\hline High & 58 \\
\hline \multicolumn{2}{|l|}{ Religion } \\
\hline Hindu & 74 \\
\hline Muslim & 12 \\
\hline Other & 14 \\
\hline \multicolumn{2}{|l|}{ Residence } \\
\hline Urban & 47 \\
\hline Rural & 53 \\
\hline \multicolumn{2}{|l|}{ Region } \\
\hline North & 20 \\
\hline Central & 18 \\
\hline West & 13 \\
\hline East & 14 \\
\hline South & 19 \\
\hline Northeast & 16 \\
\hline Total & 100 \\
\hline
\end{tabular}

logistic regressions were estimated, one each for parities $1-4$, to determine a woman's odds of progressing to the next parity according to current sex composition.

Because other factors are likely to influence parity progression, the multivariate analyses included a variety of control variables. First, child mortality may be a major motivation for having more children. A binary variable was included that indicated whether a woman had lost one or more children from prior parities at least 12 months before the birth of the last-born child. For women who stopped childbearing at a given parity, this variable indicated whether a child from any parity had died. Socioeconomic measures used in the analyses include the mother's age, her education (none, primary, secondary or more than secondary), her religion (Hindu, Muslim or other) and whether she had an occupation. * A media exposure index quantified the mother's use of TV, radio and print media (newspapers and magazines); for each category, respondents rated their exposure on a scale from 0 (never uses) to 3 (uses almost every day), yielding a total score ranging from 0 (no media exposure at all) to 9 (uses three media almost daily). Other measures included in the multivariate analyses were husband's education, whether the husband had an occupation, the household standard of living, residence (urban or rural) and region (categorized as north, central, west, east, northeast and south, as per the NFHS).

\section{RESULTS}

Sample

The average age of women in the sample was 41 years (Table 1). Forty-five percent had no education, while 46\% had a primary or secondary education and $8 \%$ had more than a secondary education. Some $45 \%$ of women reported that they had an occupation. The majority of women (58\%) lived in a household with a high standard of living, the remainder in a household with a medium (18\%) or low (24\%) standard of living. Hinduism was the dominant religion (74\%), followed by Islam (12\%); smaller proportions of women were Christian (8\%), Sikh (3\%) or members of other religions (3\%). Slightly more than half (53\%) of women lived in rural locations. On average, women had had 3.8 births (not shown).

Four percent of women who stopped childbearing at parity 1 reported that the child had died (Table 2). In contrast, $7 \%$ of those who continued childbearing reported that their first child had died. Therefore, there was a three percentage-point gap in the child death rate between women who stopped childbearing at parity 1 and those who continued to parity 2. Among women with at least two births, the gap in the death rate for the first two children between women who stopped at parity 2 and those who continued to parity 3 was 12 percentage points (6\% vs. $18 \%$ ). Similarly, the gaps between women who stopped childbearing and those who continued was 17 percentage points for parity 3 , and 13 percentage points for parity 4 .

*The occupation variable was recoded from a variable in the survey that asked:"What is your occupation?" The response options were "not working," "clerical," "agricultural self-employed," "agricultural," "skilled manual," "unskilled manual," "sales," "professional, technical, managerial" and "household and domestic." Respondents were classified as having an occupation if they gave an answer other than "not working." The rationale for using the occupation variable is to ensure proper categorization of respondents who have seasonal jobs (especially in rural areas); asking such individuals whether they are employed might yield misleading responses during the off-season. The same process was followed to create the binary variable for husband's occupation.

†The standard of living index in the NFHS-3 is based on the household's ownership of 19 durable goods and four means of transport, whether the household is covered through a health scheme and whether the household has a Below Poverty Line card. On the basis of their scores, households were divided into five quintiles; in this analysis, a household's standard of living was recoded as being low (the two poorest quintiles) medium (the middle quintile) or high (the two wealthiest quintiles). 


\section{Parity Progression}

Of the 33,245 women who had a first birth, 93\% of those who had a son and $95 \%$ of those who had a daughter had at least one subsequent birth (Table 3). At parity 2, 85\% of women with no sons moved to parity 3 ; this proportion dropped to $73 \%$ for women with one son, and to $70 \%$ for women with two sons. At parity 3, 84\% of women with no sons progressed to the next parity, compared with $68 \%$ of women with one son, $58 \%$ of women with two sons and $64 \%$ of those with three sons. At parity 4 , women with no sons had an $81 \%$ chance of moving to parity 5 ; the proportion dropped to $67 \%$ for women with one son, $56 \%$ for women with two sons, $57 \%$ for women with three sons, and $66 \%$ for women with four sons.

- Excess number of annual births. The above results suggest that the desire for sons drives parity progression. To estimate the excess fertility driven by desire for sons, the number of births that would have occurred at each parity if parents had had no gender preference was calculated. An underlying assumption in these calculations was that the minimum parity progression percentages in Table 3 would prevail at each parity, regardless of sex composition; thus, $93 \%$ of women would move from parity 1 to $2,70 \%$ from parity 2 to 3 , and so on. ${ }^{19}$ In this scenario, the number of live births that would have occurred by parity 5 is 104,667 , or 8,138 fewer than the observed total of 112,805 . This suggests that $7 \%$ of births by parity 5 in the sample can be attributed to differential probabilities of parity progression driven by a desire for sons.

\section{Sex Ratio at Birth of Last-Born Child}

An alternative analytic approach is to compare, for each parity, the sex ratio of the last-born child among women who had stopped childbearing with the ratio among those who had a subsequent birth. If the desire for sons motivates progression to the subsequent parity, then women may be more likely to stop childbearing if their last-born child was a son rather than a daughter. If this is the case, then the sex ratio at the birth of the last-born child of women who have stopped childbearing would be greater than the biologically expected ratio of 105 males for every 100 females. ${ }^{28,30}$ Conversely, women would be expected to be more likely to continue childbearing if their last-born child was a daughter; as a result, the sex ratio at birth among children of women who continue childbearing would be less than 105. The NSFH-3 data support this hypothesis. Among Indian women who stopped childbearing at parity 1 , the sex ratio at birth was 143 males for every 100 females (Table 4, page 182). In contrast, the sex ratio at birth was 106 among women who continued childbearing. At parity 2, the sex ratio at birth was 153 among women who had no more children, but only 98 among women who continued to have children. Similarly, sex ratios at birth were substantially higher among women who stopped childbearing than among those who had additional children at parity 3 (157 vs. 94), parity 4 (139 vs. 93) and parity 5 (133 vs. 96).

\begin{tabular}{|c|c|c|c|c|}
\hline \multirow[t]{2}{*}{ Characteristic } & \multicolumn{4}{|c|}{ Parity } \\
\hline & 1 & 2 & 3 & 4 \\
\hline \multicolumn{5}{|l|}{$\begin{array}{l}\text { PERCENTAGE DISTRIBUTIONS } \\
\text { No. of sons }\end{array}$} \\
\hline 0 & 48 & 23 & 12 & 7 \\
\hline 1 & 52 & 50 & 37 & 26 \\
\hline 2 & na & 27 & 38 & 37 \\
\hline 3 & na & na & 13 & 23 \\
\hline 4 & na & na & na & 6 \\
\hline Total & 100 & 100 & 100 & 100 \\
\hline \multicolumn{5}{|l|}{$\begin{array}{l}\text { PERCENTAGES } \\
\text { Ever had a child who died }\end{array}$} \\
\hline $\begin{array}{l}\text { at parity } \\
\text { Women who progressed to }\end{array}$ & 4 & 6 & 15 & 32 \\
\hline next parity & 7 & 18 & 32 & 45 \\
\hline
\end{tabular}

Notes: Percentages may not total 100 because of rounding. na=not applicable.

\section{Family Size}

A third approach is to examine mean sex ratio by completed family size (i.e., total number of children ever born). Here, the hypothesis is that if parity progression is contingent on number of sons already born, then the sex ratio will be uneven across family sizes. Women who have more sons than daughters at earlier parities will stop childbear-

\begin{tabular}{|c|c|c|c|}
\hline $\begin{array}{l}\text { Parity/ } \\
\text { no. of sons }\end{array}$ & $\begin{array}{l}\text { No.of } \\
\text { women }\end{array}$ & $\begin{array}{l}\text { \% who } \\
\text { continued } \\
\text { childbearing }\end{array}$ & $\begin{array}{l}\text { No. of women if mini- } \\
\text { mum progression } \\
\text { percentage prevailed }\end{array}$ \\
\hline Parity 1 & 33,245 & & 33,245 \\
\hline 0 sons & & 95 (94.4-95.1) & \\
\hline 1 son & & $93(92.6-93.4)$ & \\
\hline Parity 2 & 31,237 & & 30,198 \\
\hline 0 sons & & $85(84.6-86.2)$ & \\
\hline 1 son & & 73 (72.5-73.9) & \\
\hline 2 sons & & $70(68.9-70.1)$ & \\
\hline Parity 3 & 23,482 & & 21,642 \\
\hline 0 sons & & $84(82.3-85.0)$ & \\
\hline 1 son & & $68(67.2-69.1)$ & \\
\hline 2 sons & & $58(57.4-59.5)$ & \\
\hline 3 sons & & $64(62.4-65.8)$ & \\
\hline Parity 4 & 15,463 & & 12,553 \\
\hline 0 sons & & $81(78.8-83.3)$ & \\
\hline 1 son & & $67(65.4-68.3)$ & \\
\hline 2 sons & & $56(55.1-57.7)$ & \\
\hline 3 sons & & $57(55.7-58.9)$ & \\
\hline 4 sons & & $66(62.8-68.7)$ & \\
\hline Parity 5 & 9,378 & & 7,029 \\
\hline Total & 112,805 & na & 104,667 \\
\hline
\end{tabular}




\begin{tabular}{|c|c|c|}
\hline Parity & $\begin{array}{l}\text { Stopped } \\
\text { childbearing }\end{array}$ & $\begin{array}{l}\text { Continued } \\
\text { childbearing }\end{array}$ \\
\hline 1 & 143 & 106 \\
\hline 2 & 153 & 98 \\
\hline 3 & 157 & 94 \\
\hline 4 & 139 & 93 \\
\hline 5 & 133 & 96 \\
\hline
\end{tabular}

ing and thus have smaller families. In contrast, women who have more daughters than sons at earlier parities will continue childbearing and have larger families. Consistent with this hypothesis, the mean sex ratio of all children ever born declines as completed family size increases, from 143 for a completed family size of one and 146 for a completed family size of two to 126 and 108 for completed family sizes three and four, respectively (Table 5). Mean sex ratios of all children ever born are smaller still for completed family sizes five (99) and completed family sizes six or larger (93).

\section{Multivariate Analyses}

- Sex composition. The associations between sex composition of a woman's children and the probability that she will have additional children were similar in unadjusted models (not shown) and adjusted models (Table 6) across parities, suggesting that the relationships are largely independent of socioeconomic factors. The results indicate a positive association between the proportion of daughters in a family and the odds of parity progression. At parity 1 , the odds of parity progression among women with a daughter are 1.4 times those of women with a son. At parity 2 , the odds of having another child are greater among women with two daughters (odds ratio, 3.5) or with one daughter and one son (1.3) than among women with two sons. At parity 3, the odds of parity progression are greater among women with three daughters (4.5) or two daughters and one son (1.5) than among women with three sons, but women with two sons and one daughter are less likely than women with three sons to continue childbearing (0.8). Finally, at parity 4, women with no sons (3.4) or one son (1.3) are more likely than women with four sons to have a subsequent birth; the odds of reaching parity five

\begin{tabular}{|c|c|c|}
\hline No.of births & $\%$ of women & Sex ratio \\
\hline All & na & 109 \\
\hline 1 & $6.2(5.9-6.4)$ & 143 \\
\hline 2 & $23.3(22.8-23.7)$ & 146 \\
\hline 3 & $24.1(23.6-24.5)$ & 126 \\
\hline 4 & $17.8(17.3-18.2)$ & 108 \\
\hline 5 & $11.4(11.1-11.7)$ & 99 \\
\hline$>5$ & $17.3(16.9-17.9)$ & 93 \\
\hline Total & 100.0 & na \\
\hline
\end{tabular}

are reduced, however, among women with two daughters and two sons (0.7) or one daughter and three sons (0.6).

- Other correlates. At most parities, replacement of deceased children is a significant motivator of parity progression. After adjustment for other correlates, women at parity 2 who had lost a child were substantially more likely to continue childbearing than were women whose two children were alive (odds ratio, 2.7). Similarly, having a lost a child was associated with increased odds of moving from parity 3 to parity 4 (2.6) and from parity 4 to parity 5 (1.8)

In general, women's education level was negatively associated with parity progression. For example, women with one child were less likely to continue childbearing if they had a secondary education (odds ratio, 0.5 ) or more than a secondary education (0.2) than if they had no education. At parities $2-4$, women had reduced odds of parity progression if they had a primary $(0.7-0.8)$, secondary $(0.3-$ $0.6)$ or more than secondary $(0.1-0.2)$ education than if they had no education.

Women's scores on the index of media exposure were negatively associated with parity progression in all models. For each one-point increase in women's exposure scores, the odds of reaching higher parities were reduced by 7-10\% (odds ratios, 0.9 each).

At parity 1 , the only level of husband's education associated with parity progression was primary; women whose husband had attained that level of schooling had 24\% higher odds of progressing to parity 2 than did women whose husband had no education (odds ratio, 1.2). At parities 2-4, women were less likely to have another child if their husband had a secondary ( 0.8 for each) or greater (0.6-0.7) education, rather than no education; at parity 4, the odds of parity progression were also reduced among women whose husband had a primary education (0.9).

There is some evidence that a higher standard of living was associated with a lower likelihood of parity progression. Although women's likelihood of parity progression did not differ by standard of living at parity 1 , at the next parity a high standard of living was associated with 24\% lower odds of progression than a low standard (odds ratio, 0.8 ). At parities 3 and 4 , the odds of parity progression were reduced among women with a medium (0.8-0.9) or high (0.6-0.7) standard of living. Last, religion was consistently associated with parity progression. At all four parities, the odds of continued childbearing were greater among Muslim women than among Hindu women (1.9-3.4); they also were elevated among women of other religions (1.2-1.6).

\section{DISCUSSION}

Prior research has established that the desire for sons has a significant influence on fertility behavior in Korea, ${ }^{19}$ Taiwan, ${ }^{31,32}$ Bangladesh, ${ }^{16}$ Pakistan ${ }^{33,34}$ and India. ${ }^{10,35,36}$ This study, which used NSFH-3 data on women aged 35-49 who had at least one child, also found such a relationship. One unique feature of this study is that by examining several hypotheses on the relationship between children's sex composition and women's fertility, it presents a com- 


\begin{tabular}{|c|c|c|c|c|}
\hline Measure & $\begin{array}{l}\text { Parity } 1 \\
(\mathrm{~N}=33,245)\end{array}$ & $\begin{array}{l}\text { Parity } 2 \\
(\mathrm{~N}=31,165)\end{array}$ & $\begin{array}{l}\text { Parity } 3 \\
(\mathrm{~N}=23,414)\end{array}$ & $\begin{array}{l}\text { Parity } 4 \\
(\mathrm{~N}=15,391)\end{array}$ \\
\hline \multicolumn{5}{|l|}{ No. of sons } \\
\hline 0 & $1.40(0.07)^{* *}$ & $3.48(0.16)^{* *}$ & $4.51(0.32)^{* *}$ & $3.35(0.37)^{* *}$ \\
\hline 1 & 1.00 (ref) & $1.30(0.05)^{* *}$ & $1.52(0.08)^{* *}$ & $1.28(0.10)^{* *}$ \\
\hline 2 & na & 1.00 (ref) & $0.78(0.04)^{* *}$ & $0.66(0.05)^{* *}$ \\
\hline 3 & na & na & $1.00(\mathrm{ref})$ & $0.63(0.05)^{* *}$ \\
\hline 4 & na & na & na & 1.00 (ref) \\
\hline \multicolumn{5}{|l|}{ Had a child who died } \\
\hline Yes & $1.24(0.15) \dagger$ & $2.71(0.15)^{* *}$ & $2.59(0.10)^{* *}$ & $1.77(0.07)^{* * *}$ \\
\hline No (ref) & 1.00 & 1.00 & 1.00 & 1.00 \\
\hline Age (yrs.) & $1.05(0.01)^{* *}$ & $1.07(0.00)^{* *}$ & $1.057(0.00)^{* *}$ & $1.04(0.01)^{* *}$ \\
\hline \multicolumn{5}{|l|}{ Woman's education } \\
\hline None (ref) & 1.00 & 1.00 & 1.00 & 1.00 \\
\hline Primary & $0.96(0.09)$ & $0.67(0.03)^{* *}$ & $0.70(0.03)^{* *}$ & $0.77(0.04)^{* *}$ \\
\hline Secondary & $0.50(0.04)^{* *}$ & $0.34(0.02)^{* *}$ & $0.45(0.02)^{* *}$ & $0.63(0.04)^{* *}$ \\
\hline >secondary & $0.21(0.02)^{* *}$ & $0.10(0.01)^{* *}$ & $0.16(0.02)^{* *}$ & $0.24(0.05)^{* *}$ \\
\hline \multicolumn{5}{|l|}{ Woman has occupation } \\
\hline Yes & $0.96(0.05)$ & $1.09(0.04)^{* *}$ & $1.06(0.04) \dagger$ & $1.02(0.04)$ \\
\hline No (ref) & 1.00 & 1.00 & 1.00 & 1.00 \\
\hline Media exposure index score & $0.93(0.01)^{* *}$ & $0.94(0.01)^{* *}$ & $0.92(0.01)^{* *}$ & $0.90(0.01)^{* *}$ \\
\hline \multicolumn{5}{|l|}{ Husband's education } \\
\hline None (ref) & 1.00 & 1.00 & 1.00 & 1.00 \\
\hline Primary & $1.24(0.13)^{*}$ & $0.92(0.05)$ & $0.96(0.05)$ & $0.85(0.05)^{* *}$ \\
\hline Secondary & $1.10(0.10)$ & $0.83(0.04)^{* * *}$ & $0.81(0.04)^{* *}$ & $0.75(0.04)^{* *}$ \\
\hline >secondary & $0.95(0.11)$ & $0.62(0.04)^{* *}$ & $0.70(0.05)^{* *}$ & $0.69(0.06)^{* *}$ \\
\hline \multicolumn{5}{|l|}{ Husband has occupation } \\
\hline Yes & $1.53(0.20)^{* *}$ & $1.20(0.11)^{*}$ & $1.03(0.10)$ & $0.83(0.09) \dagger$ \\
\hline No (ref) & 1.00 & 1.00 & 1.00 & 1.00 \\
\hline \multicolumn{5}{|l|}{ Standard of living } \\
\hline Low (ref) & 1.00 & 1.00 & 1.00 & 1.00 \\
\hline Medium & $1.09(0.11)$ & $1.04(0.06)$ & $0.91(0.05)^{* *}$ & $0.82(0.04)^{* *}$ \\
\hline High & $0.99(0.10)$ & $0.76(0.04)^{* *}$ & $0.70(0.04)^{* *}$ & $0.64(0.04)^{* *}$ \\
\hline \multicolumn{5}{|l|}{ Religion } \\
\hline Hindu (ref) & 1.00 & 1.00 & 1.00 & 1.00 \\
\hline Muslim & $1.93(0.19)^{* *}$ & $2.79(0.16)^{* *}$ & $3.37(0.18)^{* *}$ & $2.67(0.15)^{* *}$ \\
\hline Other & $1.22(0.09)^{*}$ & $1.17(0.06)^{* *}$ & $1.46(0.08)^{* *}$ & $1.57(0.10)^{* *}$ \\
\hline
\end{tabular}

prehensive analysis of the relationship between desire for sons and fertility behavior. In general, women with more sons than daughters were less likely to progress to higher parities than were women with more daughters than sons. Although the findings supply considerable evidence of desire for sons, parents were by no means completely averse to having daughters. The proportion of women in our sample who progressed to the next parity was lowest among women with at least two sons and at least one daughter, a result consistent with previous research that found that although parents in India desire sons more than daughters, they do want one or more daughters. One study explained this fertility preference by alluding to the Hindu custom of kanyadaan (giving away a daughter in marriage), which proponents believe earns spiritual merit for parents. ${ }^{17}$ The current analysis suggests that roughly $7 \%$ of births in India through parity 5 can be attributed to parity progression driven by a desire for sons. This finding is similar to a previous estimate that the desire for sons is responsible for about $8.4 \%$ of fertility in Calcutta, India. ${ }^{37}$

The findings also support the sibling effect hypothesis by showing a positive correlation between family size and the proportion of daughters. In this sample, families of up to four children had a disproportionate number of sons, while families with five or more children had a disproportionate number of daughters. These results are similar to those of Park and Cho, who found that in Korea, among women who had completed childbearing, the mean sex ratio was masculine for completed families with one or two children but was feminine for completed families with three or more. ${ }^{19}$

Another unique feature of this article is that it examined parity progression driven by desire for sons through formal, parity-specific multivariate regression models. This analysis showed that even after adjustment for socioeconomic factors, having a higher proportion of daughters 
was associated with significantly elevated odds of parity progression. Among other correlates, women with deceased children had elevated odds of parity progression, while women who had higher levels of education, media exposure, or wealth, or who had an educated husband, had reduced odds of parity progression.

This study has several limitations. First, although the use of cross-sectional data allows the examination of associations between variables, it does not allow conclusions on causality to be drawn. Second, the conclusions on desire for sons are based on measures of realized fertility, and not on variables that explicitly measure son preference, such as women's ideal sex ratio of children. Third, because the survey was based on retrospective self-reports, misreporting may have occurred, and inaccurate responses concerning the number and sex of children could have skewed the results on sex ratios at birth. One potential source of bias is inaccurate recall, especially concerning children who had left home. Moreover, women may have tended to exclude children who had died, especially if the death occurred soon after birth. In addition, parents in India tend to underreport the number of daughters they have. Although some researchers have contended that these types of underreporting are unlikely to be a problem in the NFHS because the interviewers are trained to probe respondents, ${ }^{38,39}$ misreporting is nonetheless likely to have led to a small bias in the results; Clark estimated that the underenumeration of female births in the NFHS may be as high as $6 \% .{ }^{10}$ A final limitation of the study is that the regression results could have been biased by the omission of other correlates of parity progression.

From a population policy perspective, the study's key finding is that $7 \%$ of births in India would be avoided if parity progression driven by the desire for sons were eliminated. Because higher levels of female education are associated with lower odds of continued childbearing, policies that encourage women's education are a possible solution for reducing parity progression and eliminating excess fertility. However, reduction in parity progression alone does not address the deep-rooted cultural issues concerning son preference. This is because parity progression is not the only method of fulfilling the desire for sons. Since the mid-1980s, sex determination technology and abortion have become increasingly accessible in India, ${ }^{40,41}$ and used together they allow parents to have smaller families, while still having the desired number of sons, by selectively aborting unwanted female fetuses. Considerable evidence points to the possibility that the sex ratio at birth has increased in India in recent decades (even while the total fertility rate has declined) as the result of sex-selective abortion. ${ }^{42}$ Although the disproportionately high sex ratio seen in the current study among last-born children could simply be due to parents' having stopped childbearing as soon as they had a male child, the likelihood exists that parents who wanted fewer births used sex determination and abortion technology to guarantee that they had a son.

The fact that higher levels of female education are as- sociated with lower odds of parity progression does not necessarily mean that more educated women have less of a desire for sons. Although some authors have contended that women's education reduces both son preference and fertility, ${ }^{9,27}$ others have pointed to the possibility that although more educated women may prefer fewer children, they may also be more "efficient" in fulfilling their desire for sons by using their greater access to sex determination and abortion technology. In that case, the negative relationship between education and parity progression may be the result of fewer females being born. ${ }^{43,44}$ One study in India reported that in 2005, the sex ratio for second births was excessively high if the firstborn child was a daughter; this was especially the case in wealthier households and among women with 10 or more years of education. ${ }^{43}$

Similar caution needs to be exercised in interpreting the negative association between wealth and parity progression. Wealth has been known to increase access to sex determination and abortion technology, especially in northern India, where gender bias is greater. Increased accessibility and affordability of sex determination and abortion services due to greater wealth could result in fewer births, but a more masculine sex ratio at birth. ${ }^{44,45}$

Population policies that focus exclusively on reducing parity progression will not solve the underlying issues of gender bias. As long as the desire for sons continues to be of central importance in determining fertility behavior, efforts to reduce fertility may be counterproductive, as parents will use sex-selective abortion to have their desired number of sons within smaller families. Either way, son desire will be achieved at the expense of the welfare of daughters.

Although policies encouraging women's education are essential to reducing parity progression, such approaches are likely to be countered by dominant patriarchal values. Therefore, there is an urgent need to challenge established patriarchal values that create the perception that sons are more valuable than daughters. Such interventions have been successful in Korea, where the sex ratio at birth, which had been the most masculine in Asia in the 1990s, returned to normal levels in 2007. Sociologists have attributed this astonishing change to rapid economic and social advancement, along with unprecedented modernization and urbanization that led to massive shifts in underlying patriarchal social structure and reduced son preference. ${ }^{46}$ Similar suitable interventions should be considered for India. Thus, comprehensive policy packages are needed that challenge underlying patriarchal values, improve women's status and thus reduce desire for sons by making daughters and sons equally valuable to parents.

\section{REFERENCES}

1. Basu D and de Jong R, Son targeting fertility behavior: some consequences and determinants, Demography, 2010, 47(2):521-536.

2. Bhat PNM and Zavier AJF, Fertility decline and gender bias in northern India, Demography, 2003, 40(4):637-657.

3. Coale AJ, Excess female mortality and the balance of the sexes 
in the population: an estimate of the number of missing females, Population and Development Review, 1991, 17(3):517-523.

4. Das Gupta M, Selective discrimination against female children in rural Punjab, India, Population and Development Review, 1987, 13(1):77-100.

5. Das Gupta M and Bhat PNM, Fertility decline and increased manifestation of sex bias in India, Population Studies, 1997, 51(3):307-315.

6. Dyson T and Moore M, On kinship structure, female autonomy, and demographic behavior in India, Population and Development Review, 1983, 9(1):35-60.

7. Kishor S, "May God give sons to all": gender and child mortality in India, American Sociological Review, 1993, 58(2):247-265.

8. Mishra V, Roy TK and Retherford RD, Sex differentials in childhood feeding, health care, and nutritional status in India, Population and Development Review, 2004, 30(2):269-295.

9. Murthi M, Guio AC and Drèze J, Mortality, fertility and gender bias in India: a district-level analysis, Population and Development Review, 1995, 21(4):745-782.

10. Clark S, Son preference and sex composition of children: evidence from India, Demography, 2000, 37(1):95-108.

11. Jensen R and Oster E, The power of TV: cable television and women's status in India, Quarterly Journal of Economics, 2009, 124(3): 1057-1094.

12. Seidl C, The desire for a son is the father of many daughters: a sex ratio paradox, Journal of Population Economics, 1995, 8(2):185-203.

13. Sheps MC, Effects on family size and sex ratio of preferences regarding the sex of children, Population Studies, 1963, 17(1):66-72.

14. Gray E and Evans A, Parity progression in Australia: What role does sex of existing children play? Australian Journal of Social Issues, 2005, 40(4):505-520

15. Leone $T$, Matthews $Z$ and Dalla Zuanna G, Impact and determinants of sex preference in Nepal, International Family Planning Perspectives, 2003, 29(2):69-75.

16. Bairagi R, Effects of sex preference on contraceptive use, abortion and fertility in Matlab, Bangladesh, International Family Planning Perspectives, 2001, 27(3):137-143.

17. Jayaraman A, Mishra V and Arnold F, The relationship of family size and composition to fertility desires, contraceptive adoption and method choice in South Asia, International Perspectives on Sexual and Reproductive Health, 2009, 35(1):29-38.

18. Bhattacharya PC, Economic development, gender inequality, and demographic outcomes: evidence from India, Population and Development Review, 2006, 32(2):263-292.

19. Park $\mathrm{CB}$ and Cho N-H, Consequences of son preference in a low-fertility society: imbalance of the sex ratio at birth in Korea, Population and Development Review, 1995, 21(1):59-84.

20. Arnold F, Choe MK and Roy TK, Son preference, the family-building process and child mortality in India, Population Studies, 1998, 52(3):301-315.

21. Jayachandran S and Kuziemko I, Why do mothers breastfeed girls less than boys? Evidence and implications for child health in India, Quarterly Journal of Economics, 2011, 126(3):1485-1538.

22. Jayaraj D, Exploring the importance of excess female mortality and discrimination in "natality" in explaining the "lowness" of the sex ratio in India, Developing Economies, 2009, 47(2):177-201.

23. Oster E, Proximate sources of population sex imbalance in India, Demography, 2009, 46(2):325-339.

24. Jensen RT, Equal treatment, unequal outcomes? Generating sex inequality through fertility behavior, unpublished manuscript, Cambridge, MA, USA: John F. Kennedy School of Government, Harvard University, 2002.

25. Rahman M and Da Vanzo J, Gender preference and birth spacing in Matlab, Bangladesh, Demography, 1993, 30(3):315-332.

26. Mace $\mathrm{R}$ and Sear R, Birth interval and the sex of children in a traditional African population: an evolutionary analysis, Journal of Biosocial Science, 1997, 29(4):499-507.

27. Drèze J and Murthi M, Fertility, education, and development: evidence from India, Population and Development Review, 2001, 27(1):33-63.

28. Arnold F, Kishor S and Roy TK, Sex-selective abortions in India, Population and Development Review, 2002, 28(4):759-785.

29. United Nations Population Division, World Population Prospects: The 2010 Revision, Highlights and Advance Tables, New York: United Nations Population Division, 2011, <http://esa.un.org/wpp/ Documentation/pdf/WPP2010_Highlights.pdf>, accessed Oct. 3, 2012.

30. Jha PK et al., Low male-to-female sex ratio of children born in India: national survey of 1.1 million households, Lancet, 2006, 367(9506):211-218.

31. Coombs LC and Sun TH, Family composition preferences in a developing culture: the case of Taiwan, 1973, Population Studies, 1978, 32(1):43-64.

32. Park $\mathrm{CB}$, The fourth Korean child: the effect of son preference on subsequent fertility, Journal of Biosocial Science, 1978, 10(1):95-106.

33. De Tray D, Son preference in Pakistan: an analysis of intentions vs. behavior, Research in Population Economics, 1984, Vol. 5 , pp.185-200.

34. Arnold F, Son preference in South Asia, in: Sathar ZA and Phillips JF, eds., Fertility Transition in South Asia, London: Oxford University Press, 2001, pp. 281-299.

35. Das N, Sex preference and fertility behavior: a study of recent Indian data, Demography, 1987, 24(4):517-530.

36. Das Gupta M et al., Why is son preference so persistent in East and South Asia? A cross-country study of China, India, and the Republic of Korea, World Bank Policy Research Working Paper, Washington, DC: World Bank, 2002, No. 2942.

37. Bairagi $R$ and Bhattacharya AK, Parental sex preference and its effects on fertility intention and contraceptive use in Calcutta, Rural Demography, 1989, 16(1-2):43-56.

38. Griffiths P, Matthews Z and Hinde A, Understanding the sex ratio in India: a simulation approach, Demography, 2000, 37(4):477-488.

39. Bhat PNM, On the quality of birth history data collected in National Family Health Survey, 1992-1993, Demography India, 1995. 24(2):245-258

40. Ahmad N, Female feticide in India, Issues in Law \& Medicine, 2010, 26(1):13-29.

41. Seth S, Sex selective feticide in India, Journal of Assisted Reproduction and Genetics, 2007, 24(5):153-154

42. Sen A, Missing women-revisited, comment, BMJ, 2003 , 327(7427):1297-1298

43. Jha PK et al., Trends in selective abortions of girls in India: analysis of nationally representative birth histories from 1990 to 2005 and census data from 1991 to 2011, Lancet, 2011, 377(9781):1921-1928.

44. Subramanian SV and Corsi DJ, Can India achieve a balance of sexes at birth? comment, Lancet, 2011, 377(9781):1893-1894.

45. Echávarri RA and Ezcurra R, Education and gender bias in the sex ratio at birth: evidence from India, Demography, 2010 47(1):249-268

46. Das Gupta M, Chung W and Shuzhuo L, Evidence for an incipient decline in numbers of missing girls in China and India, Population and Development Review, 2009, 35(2):401-416.

\section{RESUMEN}

Contexto: El deseo de tener hijos varones con frecuencia influye en el comportamiento reproductivo en la India. Las mujeres con pocos hijos varones o con una baja proporción de hijos que son varones pueden tener mayor probabilidad que otras 
mujeres de tener más hijos.

Métodos: Se utilizaron datos de mujeres de 35-49 años que participaron en la National Survey of Family Growth de 2005-2006 de la India para examinar varias hipótesis sobre la asociación entre el sexo de cada hijo que una mujer ya tiene y sus partos sucesivos. Se realizaron análisis descriptivos y se aplicaron modelos de regresión logística multivariada separados por paridad, que controlaron posibles factores de confusión.

Resultados: Las mujeres con más hijos varones que hijas, tuvieron en general menor probabilidad de continuar teniendo hijos que aquellas con más hijas que hijos; los partos que resultaron del impulso de seguir teniendo hijos en busca de un hijo varón representaron el $7 \%$ de los nacimientos. Entre las mujeres que ya habian dejado de procrear, no importa el tamaño de la familia completa, el último hijo a nacer tuvo mayor probabilidad de ser hijo varón que mujer (razones de sexo, 133-157). En análisis multivariados, las mujeres sin algún hijo varón tuvieron mayor probabilidad que las mujeres sin alguna hija de continuar teniendo hijos a niveles de paridad de 1-4 (razones de momios, 1.4-4.5). A la mayoría o todos los niveles de paridad, el continuar teniendo hijos estuvo asociado positivamente con el hecho de tener un hijo que habia muerto; y, estuvo negativamente asociado con los niveles de educación de las mujeres, exposición a los medios de comunicación y con el nivel de riqueza de la familia.

Conclusiones: El deseo de tener hijos varones parece ser una motivación significativa para seguir procreando. Si bien son esenciales las políticas de población que reducen el tamaño de la familia, también son indispensables las políticas que reducen el deseo por hijos varones al cuestionar la percepción de que los hijos son más valiosos que las hijas.

\section{RÉSUMÉ}

Contexte: Le désir d'avoir des fils influence souvent le comportement de fécondité en Inde. Les femmes dont le nombre ou la proportion de fils est faible sont parfois plus susceptibles que les autres de continuer à avoir des enfants.

Méthodes: Les données de l'Enquête nationale indienne 2005-2006 sur la santé familiale ont servi à examiner plusieurs hypothèses relatives à l'association entre la répartition par sexe des enfants et l'élargissement de la famille parmi les femmes déjà mères âgées de 35 à 49 ans. Les analyses descriptives et celles de régression logistique multivariées de contrôle des variables de confusion éventuelles ont été exécutées séparément par parité.

Résultats: Les femmes mères d'un plus grand nombre de fils que de filles sont généralement moins susceptibles que l'inverse de continuer à avoir des enfants. L'élargissement des familles imputable au désir d'avoir des fils représente $7 \%$ des naissances. À toute parité donnée, le dernier-né des fermmes ayant arrêté d'avoir des enfants est plus généralement un fils qu'une fille (rapports de masculinité de 133 à 157). Dans les analyses multivariées, les femmes sans fils sont plus susceptibles que celles sans filles de continuer à avoir des enfants aux parités 1-4 (RC, 1,4-4,5). À la plupart des parités si pas à toutes, la procréation continue est associée positivement à la mort d'un enfant et négativement aux niveaux d'éducation et d'exposition médiatique de la femme et à la richesse du ménage.

Conclusions: Le désir d'avoir des fils semble motiver significativement l'élargissement des familles. Les politiques démographiques visant à réduire la taille des familles sont essentielles, mais il est impératif aussi d'amoindrir le désir d'avoir des fils en remettant en question la perception de la valeur supérieure de ces derniers par rapport aux filles.

Author contact: chaudhs@uwec.edu 